\title{
DEFICIENCIES KNOWN AND SUSPECTED IN LIVE-STOCK NUTRITION OF NEW ZEALAND.
}

\author{
THE PRESENT POSITION AND FUTURE WORK.
}

\author{
C. S. M. HopkiRk, 'Officer in Charge, Neterinary Laboratory, Department of \\ Agriculture, Wallaceville.
}

Numerous instances have been recorded in New Zealand in which domestic animals have failed to grow or to produce to their full capacity through the entire lack of or the reduction to a low lcvel of some of the essential food factors required by the body Deficiencies of iodine and phosphorus undoubtedly exist as such, while cobalt. and iron deficiencies are as yet interrelated. Calcium and magnesium deficiencies may or may not exist, while -protein deficiency is also to be considered only as a possibility. Vitamin deficiencies, particularly $\mathrm{A}$ and $\mathrm{D}$, may exist in intensively fed stock such as pigs and poultry, but except in pigs arc to-day relatively unimportant in New Zealand live-stock feeding.

\section{IODINE.}

A considerable 'amount of analysis of New Zealand food, water and soils has been performed by Hercus and his co-workers. More recently Mason and Sykes, working in the Chemical Laboratory of the Department of Agriculture, have carried out extensive analyses of thyroid glands of lambs in an attempt to survey the iodine content of districts. Shore and Andrews have also added considerably to the knowledge of the position in certain parts of New Zealand. The survey is now well forward, and is being continued by the Department of Agriculture, with the result that the deficient areas of New Zealand are fairly well mapped out.

Iodine deficiency generally in New Zealand is not considered sufficiently widespread to cause hairlessness and mortality in young pigs, nor to interfere to any extent with the assimilation of calcium and phosphorus nor the productidn of milk. There are, however, to be seen cases of goitre in calves and lambs in districts known to be 'low in iodine and where salt-licks have not been provided. Such an example was reported at Wanaka by Dayus and others. Incipient goitre may also be noted in calves in deficient areas, as reported by Webster in North Taranaki. Provided that an iodizedsalt lick is used in known deficient areas, there is no necessity to add potassium iodide to licks in a general way as fashion prompted some years ago.

So much critical work has been performed on endemic goitre as opposed to exophthalmic goitre that it is now practically an accepted fact that endemic goitre results from a deficiency of iodine in the food intake, or, because of poor assimilation of the iodine present. That being so, all that remains for workers in New Zealand to do is to map clearly areas of shortage quantitatively so that the necessary iodized-salt. licks or foods rich in 
126

iodine may be given to domestic animals in those areas. Such work belongs to the chemist and soil-survey officers, 'but correlation of. this "work with animal disease should also: be considered. ""

Phosphorus:

Phosphorus is the limiting factor in development of the skeleton, milk-production, and œstrum. There is usually a greater deficiency of phosphorus in the food intake "than there is of calcium,' but it is necessary to have some optimum balance between calcium and phosphorus to get the best results in production and reproduction.

There is considerable variation in calcium and phosphorus in $\mathrm{New}$, Zealand pastures. Where intensive dairying is carried out the pasture analysis shows that the richest pastures contain I part each of calcium and phosphorus in 100 parts of dried material. Where restrum is failing, phosphorus has probably dropped to 0.2 per cent., while rickets and osteoporosis occur at slightly higher levels in growing animals. An excess of calcium can so bind phosphorus that the animal remains deficient. even though the quantity of phosphorus with a lowered calcium would be sufficient for ordinary purposes of animal metabolism. Bonesoftening (osteomalacia) may be due to deficiency of vitamin D. preventing assimilation of calcium and phosphorus as in pigs and dogs, to excess of phosphorus over calcium as in lambs on green oats, and in horses, or to deficiency of phosphorus al one, largely seen in herbivora. This latter is the more common. Phosphorus defidency is New Zealand has always been common, and acute phosphorus deficiency was given the name "Waihi disease " in earlier days. Fragility of bone and lack of sufficient phosphorus in the soil and pasture led to medicinal treatment with iron phosphates and to soil top-dressing with bonedust, and later with superphosphate. Because of the habit of stock of chewing -bones when phosphorus deficiency developed, green bone was given to cattle, and later steamed bone flour was given in salt as a lick. As bone flour contained calcium as well as phosphorus, the provision of a bone-flour lick was a rational form of treatment, and, where the soil itself could not be treated by top-dressing, still is a very useful method of giving phosphorus to stock. By its use many areas of $\mathrm{New}$ Zealand have increased their calf and lamb crop from 40 per cent. to go per cent. and over, and have very greatly increased the milk-yield of both ewes and cows.

The rational use of superphosphate' as a means of increasing production is to be commended, but the use of enormous quantities of superphosphate alone on land already low in calcium is to be deplored, for it- may easily defeat its own object and bring about deficiency of calcium in the body and cause stock ailment.

It can be assumed that almost any part of New Zealand not using some form of phosphatic top-dressing is deficent in phosphorus. That being so, it is advisable that stock-licks composed of bone flour and salt should at all times be provided for stock, and more particularly for dairy cows, the phosphorus excretion of which is so extraordinarily heavy.

Research work on phosphorus assimilation in stock is by no means finished, but the more important aspect is the finding of the correct balance between phosphorus and such other minerals as magnesium and calcium, and other food constituents such as protein. This latter 
aspect is one in which drought areas are more interested. Blood chemistry has become helpful in diagnosis, but still is full of pitfalls, while bone analysis of animals can be used to some extent to map out. deficient areas.

\section{A L C I U M .}

As has been discussed already, calcium is largely bound up with phosphorus in animal metabolism, and it is advisable to maintain a reasonable balance between the two minerals. Rickets is frequently considered to be due to calcium deficiency, but Sir Arnold Theiler taught that the limiting factor can always be found to be phosphorus in bone troubles of stock.. It would, however, be reasonable to assume that with low calcium and high phosphate, as in green oats, upon which growing lambs become bandy, the low calcium is as limiting a factor if not more so than the phosphorus. In such feeding the calcium is still further bound by the high phosphorus.

Although very little real proof exists, milk fever and bloat in dairy cows and sheep are believed by some workers to be due in part to the lack of balance of calcium and phosphorus. 'The hypocalcremia which is present during the coma of milk fever is cured by addition of calcium to the blood-stream, and appears to be prevented by the addition of burnt lime to drinking-water or to soil prior to calving. It has also been noticed that an increase of lime to pastures has prevented bloat, but it is not possible to show by analysis of blood or bones of animals that there has been an actual shortage of calcium. The shortage may have been sufficient in the case of bloat, however, over a long period to produce a lack of tone in ' the alimentary system.

Much work could. be performed in certain districts on the effect of lime in prevention of bloat and milk fever, taking into consideration the possible change in pasture-plants brought about by top-dressing and the chemical change in organs of the animals. The effect of deficiencies of calcium and magnesium on parathyroid of cattle and sheep and the detrimental effect of increases of phosphorus could very profitably be examined.

\section{MAGNESIUM.}

In some of the particularly rich dairying districts of the North Island a condition in cows known as "grass staggers" occurs shortly after calving in the early spring. Investigation has shown that the blood is temporarily deficient in magnesium yet the total quantity of magnesium in the body has not been lowered. Analysis of pasture has shown no deficiency of magnesium, but there is usually a high phosphorus content and a tendency for a low calcium content. "Grass staggers," post partum paralysis, and milk fever seem to occur on the same farms, and it would appear that there is a lack of balance of phosphorus as against magnesium and calcium.

Trials of feeding of dolomite and magnesium sulphate in silage, licks, or drinking-water have been carried out fairly extensively, and one believes that by such methods of increasing the bodily content of magnesium that the animals can resist " grass staggers." It has been noted that there is a definite temporary drop of magnesium in the blood of animals placed on rich pasture after a winter feeding of hay and non-growing poor 'grass. Future work must be carried out to find the 
reason for this temporary drop of blood-magnesium, and such work 'would appear to be bound up with the practice of superphosphate top-dressing, or else with the use of selected strains of grasses.

IroN AND COBALT.

For many years Aston's theory of a definite iron deficiency being causative of anæmia in ruminants in certain areas of the $\mathrm{N}$ orth Island was rigidly adhered to and accepted as a reason for anæmia and death not only in N ew Zealand, but in other well-known areas of the world. Aston's finding and utilization. of limonite as a commercial source of crudeiron for preventing bush sickness was epoch-making. The fac that burnt linionite and limonite from other sources than the original were inert gave the clue to the possibility of other metals present in limonite in trace quantities being necessary for iron assimilation or for themselves alone. Already at this stage it was known in Florida that copper was required in conjunction with iron. Filmer and Underwood in Austraha, finding that some other substance was contained in limonite, and that probably cobalt or nickel was the active. material, led to work in South A ustralia by Marston and in N ew Zealand by Rigg and others at Cawthron, with the result that cobalt can now be used as a preventive in salt licks at the rate of $\mathbf{2} \mathrm{Oz}$. to the ton of salt in certain South Island areas previously considered bush sick or nearly so. Similar work is about to be carried out in the North Island. Trace elements such as cobalt are found remarkably deficient in some areas of N ew Zealand, and cobalt is almost absent in many of the volcanic showers and in places such as Morton Mains. It would seem unnecessary to give iron as such in these known deficient areas, and to give in its stead a cobalt salt. Therefore, if that be so, one is not correct in speaking now of an iron'deficiency.

The interaction of cobalt and iron in prophylaxis is not properly known, and whether cobalt acts as a direct blood-cell stimulant only or has some catalytic action on iron as well remains to be seen. Cobalt in excess will increase the number of reticulocytes and the hæmoglobin in blood, a fact which has recently been demonstrated in rats at Wallaceville. The work on this problem must be experimental, on farms in affected areas, but it must be well controlled. Blood histology and chemistry is necessary to put the pathology of the disease on a proper footing. A continuation of soil survey, soil and pasture chemistry, and analysis of animal organs from experimental animals is also part of the research programme. Also production of anamia in experimental feeding of cobalt-free diets would be of very great use. How a definite deficiency of cobalt or other minerals can exist without affecting animals such as horses, pigs, and rabbits is a matter for investigation.

\section{Vitamins.}

Vitamin deficiencies can exist only under conditions of -poor husbandry, and are not dependent on deficiencies in soil and pasture to any extent, with the possible exception of vitamin A in drought seasons and in swine husbandry. They do not, therefore, come within the scope of this paper. 


\section{9}

Protein

Total-protein deficiency can exist on poor pastures, again mainly under drought conditions. Such a deficiency causes sarcophagia in animals, but with such favourablc climatic conditions as exist in New Zealand one would scarcely expect to see evidence of lack of total protein. There may, however, be a deficiency of certain aminoacids-that is, the food of stock may' not be rich enough in complete proteins. This is considered to be a possibility in male infertility. It is known that high protein can cause malc infertility in rat experimental work, and also that incomplete protein can also set up a similar testicular atrophy. The work on rats is at present being carried out on diets known to be incomplete in protein but complete in all other forms of food. Additional amino-acids are being fed with this basal diet. Considerable chemical assistance is required to list the amino-acid content of the pastures, animal organs, and experimental foods before this rat work will be completed. In turn the rat work has still to be repeated on domestic animals and so become translated into field practice.

Discussion.

(Follows next paper.) 